INTEGRATIVE LITERATURE REVIEW ARTICLE

DIFFICULTIES IN ACCESS TO HEALTH SERVICES BY LESBIANS, GAYS, BISEXUALS AND TRANSGENDER PEOPLE

\title{
DIFICULDADES NO ACESSO AOS SERVIÇOS DE SAÚDE POR LÉSBICAS, GAYS, BISSEXUAIS E
} TRANSGÊNEROS

\author{
DIFICULTADES DE ACCESO A LOS SERVICIOS DE SALUD POR LESBIANAS, GAYS, BISEXUALES Y \\ TRANSGÉNITOS
}

Alef Diogo da Silva Santana ${ }^{1}$, Marcos Soares de Lima² ${ }^{\mathbb{D}}$, Jefferson Wildes da Silva Moura ${ }^{(\mathbb{D}}$, Isabel Cristina Sibalde Vanderley ${ }^{4}$ i⿺ Ednaldo Cavalcante de Araújo ${ }^{5}$

\section{ABSTRACT}

Objective: to analyze the difficulties of access to health services by LGBT people. Method: this is a descriptive bibliographic study of the integrative literature review type. The search was performed in January 2019 in the databases: MEDLINE, Web of Science and SCOPUS. We searched for articles with timeless delimitation. The articles were evaluated according to the AHRQ criteria and their eligibility by CASP. Data was analyzed in the IRAMUTEQ software from the Descending Hierarchical Classification. Results: it is noteworthy that the final sample consisted of ten articles, among them, $70 \%$ were available at SCOPUS; $10 \%$ on Web of Science and $20 \%$ on MEDLINE. Regarding the nationality of the studies, $10 \%$ were from Germany; $10 \%$ from Brazil; $10 \%$ from Argentina; $20 \%$ from Canada; $20 \%$ from South Africa and 30\% from the United States of America. It was found that the years of publication of the studies were between 2013 and 2018. Conclusion: it is evident that access to health services by the LGBT population is permeated by constraints and prejudices. It is emphasized that exclusion, helplessness, omission and indifference to access are feelings expressed by this public, even though there are specific public policies. Descriptors: Health Services; Sexual and Gender Minorities; Health Services Accessibility; Nursing; Health Vulnerability; Public Policy.

\section{RESUMO}

Objetivo: analisar as dificuldades de acesso aos serviços de saúde pelas pessoas LGBT. Método: trata-se de um estudo bibliográfico, descritivo, do tipo revisão integrativa da literatura. Realizou-se a busca em janeiro de 2019 nas bases de dados: MEDLINE, Web of Science e SCOPUS. Pesquisaram-se artigos com delimitação atemporal. Avaliaram-se os artigos segundo o critério AHRQ e sua elegibilidade pelo CASP. Analisaram-se os dados no software IRAMUTEQ a partir da Classificação Hierárquica Descendente. Resultados: destaca-se que a amostra final foi composta por dez artigos, entre eles, 70\% encontraram-se disponíveis na SCOPUS; 10\%, na Web of Science e 20\%, na MEDLINE. Notou-se que, referente à nacionalidade dos estudos, $10 \%$ foram da Alemanha; $10 \%$, do Brasil; $10 \%$, da Argentina; $20 \%$, do Canadá; $20 \%$, da África do Sul e 30\%, dos Estados Unidos da América. Verificou-se que os anos de publicação dos estudos foram entre 2013 e 2018. Conclusão: evidencia-se que o acesso aos serviços de saúde pela população LGBT é permeado por constrangimentos e preconceitos. Ressalta-se que a exclusão, desamparo, omissão e indiferença ao acesso são sentimentos expressados por este público, mesmo existindo políticas públicas específicas. Descritores: Serviços de Saúde; Minorias Sexuais e de Gênero; Acesso aos Serviços de Saúde; Enfermagem; Vulnerabilidade em Saúde; Política Pública.

\section{RESUMEN}

Objetivo: analizar las dificultades de acceso a los servicios de salud por parte de las personas LGBT. Método: este es un estudio bibliográfico descriptivo del tipo revisión integradora de literatura. La búsqueda se realizó en enero de 2019 en las bases de datos MEDLINE, Web of Science y SCOPUS. Buscamos artículos con delimitación atemporal. Los artículos fueron evaluados de acuerdo con los criterios AHRQ y su elegibilidad por CASP. Los datos se analizaron en el software IRAMUTEQ de la Clasificación Jerárquica Descendente. Resultados: cabe destacar que la muestra final consistió en 10 artículos, entre ellos, $70 \%$ estaban disponibles en SCOPUS, $10 \%$ en Web of Science y $20 \%$ en Medline. Con respecto a la nacionalidad de los estudios, el 10\% provino de Alemania, el 10\% de Brasil, el 10\% de Argentina, el 20\% de Canadá, el $20 \%$ de Sudáfrica y el 30\% de los Estados Unidos de América. Se descubrió que los años de publicación de los estudios fueron entre 2013 y 2018. Conclusión: es evidente que el acceso a los servicios de salud por parte de la población LGBT está impregnado de restricciones y prejuicios. Es de destacar que la exclusión, la impotencia, la omisión y la indiferencia al acceso son sentimientos expresados por este público, a pesar de que existen políticas públicas específicas. Descriptores: Servicios de Salud; Minorías Sexuales y de Género; Accesibilidad a los Servicios de Salud; Enfermería; Vulnerabilidad en Salud; Política Pública.

1,3,4,5Federal University of Pernambuco/UFPE. Recife (PE), Brazil. 1https://orcid.org/0000-0001-8165-6412 20https://orcid.org/0000-0002-07215771 30https://orcid.org/0000-0002-7192-1099 4- 4https://orcid.org/0000-0003-0372-9481 50https://orcid.org/0000-0002-1834-4544 ${ }^{2}$ University of Pernambuco/UPE. Recife (PE), Brazil. 210https://orcid.org/0000-0002-0721-5771. 


\section{INTRODUCTION}

It is understood that health is a universal right and the result of a historical and social process ratified in the Brazilian Federative Constitution of 1988. ${ }^{1}$ Through the Unified Health System (UHS), the aim is to promote health for all, including both basic and complex care through universality, comprehensiveness and equity. ${ }^{1}$ It is evident, however, that even though advocated by law that health is a right of all and subsequently the National Policy for Integral Health to Lesbians, Gay, Bisexual, Transvestite and Transgender (LGBT) was implemented, access to health for their population still faces major obstacles. ${ }^{2}$

In 2011, the National LGBT Comprehensive Health Policy was launched, through Ordinance No. 2,836, with the objective of guaranteeing equity, respect and health care for the specificities of the LGBT community, as a result of the recognition of the effects of discrimination, marginalization and exclusion. ${ }^{2}$ Its principles are geared towards changes in the social determination of health, with a view to reducing social inequalities and vulnerabilities, in addition to recognizing the singularities and establishing objective proposals to be executed in all spheres of management of the Unified Health System (UHS). ${ }^{2}$

It is evident that the vulnerabilities experienced by LGBT people are linked to prejudice, omission of rights, social stigma, invisibility and the difficulty of access to health services, which constitute the main barriers to the non-realization of a well-being. being biopsychosocial, thus requiring the implementation of public policies for health promotion and the reduction of LGBT phobia in social and health settings. ${ }^{3}$

It has been shown in studies ${ }^{4-5}$ that the difficulties experienced by LGBT people impact prejudice, intimidation, un (humanized) and unethical practices by health professionals, as well as the unpreparedness of professionals in meeting the specificities of LGBT people.

It stands out in studies, ${ }^{6-7}$ LGBT people omit their sexual orientation or gender identity when seeking help from health professionals, and avoid following up on health services because of fear of disgust and facing obstacles to care. ${ }^{6}$ It is noted that health professionals have a responsibility to identify and understand the factors that interfere and harm LGBT people in the health-disease process, as well as enabling care in a nonbiologicist, integral and that relates to aspects that go beyond cisnormative and binary model. ${ }^{7}$

Thus, it is perceived that the LGBT population, daily, faces numerous obstacles that hinder their search and adherence to health services. LGBT phobia, parental and social rejection, disrespect and lack of information on the specificities of LGBT people by health professionals, discrimination and social stigma are factors that interrelate, culminating in the difficulty access to LGBT people in health services. ${ }^{8}$

\section{OBJECTIVE}

- To analyze the difficulties of access to health services by LGBT people.

\section{METHOD}

This is a bibliographic, descriptive, integrative review (RI) study, conducted in six stages: 1) problem establishment; 2) sample selection; 3) data extraction from primary studies; 4) evaluation of primary studies included in the review; 5) analysis and synthesis of the review results and 6) presentation of the integrative review. ${ }^{9-10}$

The PICo ${ }^{11}$ strategy was used to elaborate the guiding question ( $\mathrm{P}$ : sexual and gender minorities; I: difficulties in care; Co: access to health services), namely: "What are the difficulties of access to LGBT people in health services?".

The articles were searched in pairs, from December 12, 2018 to January 21, 2019, using the advanced database search form: Medical Literature Analysis and Retrieval System Online (MEDLINE), Web of Science and SCOPUS.

The articles were searched from the Descriptors in Health Sciences (DeCS): "Health Services"; "Sexual and gender minorities"; "Access to health services"; "Nursing"; "Health Vulnerability"; "public policy". The respective terms from Medical Subject Headings (MeSH) were used: "Health services'; "Sexual and gender minorities"; “Access to health services"; Nursing; Health Vulnerability; "Public Policy".

Full original articles with timeless delimitation, published in Portuguese, English or Spanish, which met the objective of the study and which allowed access through the Virtual Private Network (VPN) of the Federal University of Pernambuco (UFPE), were included. Repeated articles from the gray literature whose purpose was not publishing were excluded. The timeless study is justified because the LGBT population suffers stigmas related to the health-disease process in a historical-social process. ${ }^{12}$

After locating the articles, two authors independently read the title, abstract and descriptors, showing divergences, and a third researcher read both articles. At the end of this process, ten articles were.

The level of evidence was assessed with the Agency for Healthcare Research and Quality (AHRQ), which comprises the following levels: level 1 - meta-analysis of multiple controlled studies; level 2 - individual study with 
experimental design; level 3 - study with quasiexperimental design as non-randomized study with single group pre and post test, time series or case control; level 4 - study with non-experimental design as a correlative and qualitative descriptive research or case studies; level 5 - case report or data obtained systematically from verifiable quality or program evaluation data; level 6 opinion of respected authorities based on clinical competence or opinion. ${ }^{13}$

The adapted instrument Systematic review of the Critical Appraisal Skills Program (CASP) Critical Reading Skills Program, part of the Public Health Resource Unit - PHRU, was used to evaluate manuscript eligibility. ${ }^{14}$ This instrument consists of answers of type "yes or no" and their respective scores (one point and zero point) being the result presented by the sum of all items. Thus, studies are classified in two levels: " $A$ " (six to ten points) - Studies of good methodological quality and reduced bias and " $B$ " (up to five points) Studies with satisfactory methodological quality, but with potential for increased bias. ${ }^{14}$ In this study, articles with concept "A".

For the presentation of the results, the flowchart Preferred Reporting Items for Systematic Reviews and Meta-Analyzes (PRISMA) was used, and it is possible to obtain the analysis of this review in figure $1 .^{15}$

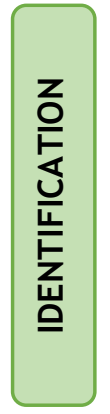

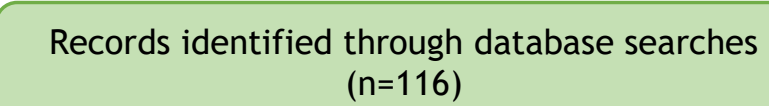

$(n=116)$
Records identified through searches in other data sources $(n=00)$

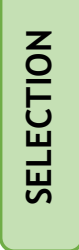

Records after deleting duplicate studies $(n=28)$

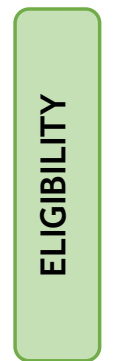

\section{Complete studies evaluated for} eligibility $(n=24)$
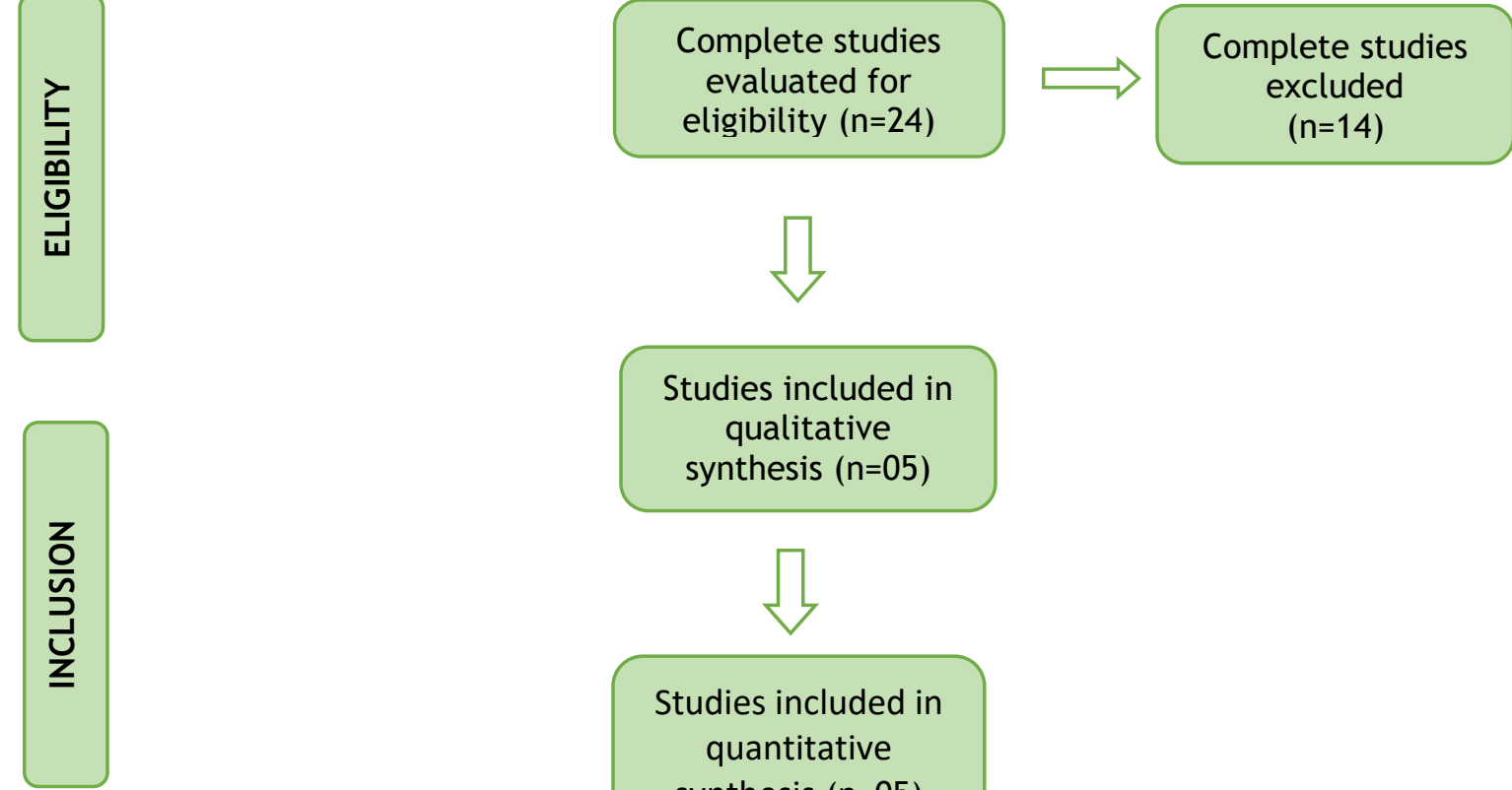

Studies included in qualitative synthesis $(n=05)$

Figure 1. Flowchart of the process of inclusion of scientific articles adapted from PRISMA. Recife (PE), Brazil, 2019.

The summarization of the corpus information was obtained through an instrument ${ }^{16}$ : identification of the original article; authorship of the article; year of publication; parents; methodological characteristics of the study; study sample and evaluation of the methodological rigor of the interventions applied and the results. Data was analyzed using the Software Interface for Multidimensional Analysis of Textes and Questionnaires (IRAMUTEQ), version 7.0, which allowed the analysis of the Descending Hierarchical Classification (CHD). ${ }^{16-7}$

For the formation of the textual corpus, the original contributions of the primary studies taken from the results, discussion and conclusion were considered. Contributions were verified with scientific and methodological rigor, being analyzed by $\mathrm{CHD}{ }^{15}$ The dendogram with the classes was generated through analysis and processing of the corpus by CHD (Figure 3), which 
illustrates the classes obtained from the textual corpus. Words with $\mathrm{p}<0.05$ and chi-square (X2) were considered statistically significant when analyzing the value of class association ( $\geq 15.19) .{ }^{17}$

\section{RESULTS}

Initially, 116 publications were identified in the search for databases. Subsequently, titles and abstracts were read and the inclusion and exclusion criteria were applied, considering, in this phase, 24 primary studies for full reading and, after analyzing those who answered the guiding question and the application of the evidence level instrument and CASP, ten of them were.
Of the primary studies, seven $(70 \%)$ were available from SCOPUS, one (10\%) from Web of Science and two (20\%) from MEDLINE. Regarding the nationality of the studies, one $(10 \%)$ was from Germany, one (10\%), from Brazil, one (10\%), from Argentina, two (20\%), from Canada, two (20\%). \%) from South Africa and three (30\%) from the United States of America. Considering the objectives, six $(60 \%)$ of them spoke about barriers to access to health by the LGBT population in general, three (30\%) explained about the social vulnerability of LGBT women when seeking access to health services. and one $(10 \%)$ focused on the invisibility of LGBT people, as shown in figure 2.

\begin{tabular}{|c|c|c|c|c|}
\hline Author & Year & Country & Journal & Type of study \\
\hline James, Adena, Sarah, Brian ${ }^{4}$ & 2016 & USA & $\begin{array}{l}\text { American } \\
\text { Journal of } \\
\text { Public Health }\end{array}$ & Quantitative \\
\hline Macapagal, Bhatia, Greene ${ }^{5}$ & 2016 & USA & LGBT Health & Longitudinal \\
\hline $\begin{array}{l}\text { Oliveira, Nogueira, Costa, Silva, } \\
\text { Almeida }^{6}\end{array}$ & 2018 & Brazil & Rene Journal & Qualitative \\
\hline $\begin{array}{l}\text { Seibel, Falceto, Hollist, Springer, } \\
\text { Fernandes, Koller }{ }^{7}\end{array}$ & 2016 & Argentina & $\begin{array}{l}\text { Families } \\
\text { Thinkin }\end{array}$ & $\begin{array}{l}\text { Descriptive, } \\
\text { and cross- } \\
\text { sectional } \\
\text { cohort }\end{array}$ \\
\hline Hirsch, Löltgen, Becker ${ }^{18}$ & 2016 & Germany & $\begin{array}{l}\text { BMC Family } \\
\text { Practice }\end{array}$ & Quantitative \\
\hline Müller, Spencer, Meer, Daskilewicz ${ }^{19}$ & 2018 & $\begin{array}{l}\text { South } \\
\text { Africa }\end{array}$ & $\begin{array}{l}\text { BMC } \\
\text { Reproductive } \\
\text { Health }\end{array}$ & Qualitative \\
\hline Müller ${ }^{20}$ & 2017 & $\begin{array}{l}\text { South } \\
\text { Africa }\end{array}$ & $\begin{array}{l}\text { BMC } \\
\text { International } \\
\text { Health and } \\
\text { Human Rights }\end{array}$ & Qualitative \\
\hline Fredericksa, Harbinb, Bakerc21 & 2016 & Canada & $\begin{array}{l}\text { Health care } \\
\text { for Women } \\
\text { International }\end{array}$ & Qualitative \\
\hline Bradford, Reisner, Honnold, Xavier 22 & 2013 & USA & $\begin{array}{l}\text { American } \\
\text { Journal of } \\
\text { Public Health }\end{array}$ & $\begin{array}{l}\text { Quantitative } \\
\text { and cross } \\
\text { sectional }\end{array}$ \\
\hline $\begin{array}{l}\text { Abra, Tarasoff, Green, Epstein, } \\
\text { Anderson, Marvel, et al. }{ }^{23}\end{array}$ & 2015 & Canada & $\begin{array}{l}\text { Human } \\
\text { Reproduction }\end{array}$ & Qualitative \\
\hline
\end{tabular}

Figure 2. Distribution of articles included in the sample by authors' name, year, country, journal and method. Recife (PE), Brazil, 2019. 


\begin{tabular}{|c|c|}
\hline & \\
\hline $\begin{array}{l}\text { arriers to health care among } \\
\text { Iults identifying as sexual } \\
\text { inorities: a US National Study. }{ }^{4}\end{array}$ & $\begin{array}{l}\text { ealth care are encountered, } \\
\text { to delay or non-delivery, as } \\
\text { ost and problems of finding a } \\
\text { e. }\end{array}$ \\
\hline $\begin{array}{l}\text { Differences in healthcare access, } \\
\text { use, and experiences within a } \\
\text { community sample of racially } \\
\text { diverse lesbian, gay, bisexual, } \\
\text { transgender, and questioning } \\
\text { emerging adults. }{ }^{5}\end{array}$ & $\begin{array}{l}\text { sity } \\
\text { en. } \\
\text { to } \\
\text { lth }\end{array}$ \\
\hline $\begin{array}{l}\text { ccess by lesbians, gays, bisexuals } \\
\text { nd transvestites/transsexuals to } \\
\text { he basic family health units. }{ }^{6}\end{array}$ & $\begin{array}{l}\text { LGBT people are often said to omit their } \\
\text { sexual orientation and gender identity } \\
\text { when seeking help or support from basic } \\
\text { family health facilities. Homophobic } \\
\text { manifestations, indifference and } \\
\text { embarrassment in care, un (humanized) } \\
\text { and unethical practices by health } \\
\text { professionals are mentioned. }\end{array}$ \\
\hline $\begin{array}{l}\text { Barreras en la atención de la salud } \\
\text { sexualen Argentina: percepción de } \\
\text { las mujeres que tienen sexo con } \\
\text { mujeres. }\end{array}$ & $\begin{array}{l}\text { It is believed that women } \\
\text { with other women, by ex } \\
\text { sexuality in a health cons } \\
\text { provoke negative reactions a } \\
\text { exposure to health professio }\end{array}$ \\
\hline $\begin{array}{l}\text { esbian womens' access } \\
\text { ealthcare, experiences with and } \\
\text { xpectations towards GPs in } \\
\text { erman primary care. }{ }^{18}\end{array}$ & $\begin{array}{l}\text { It is evident that lesbian women fail to } \\
\text { undergo necessary examinations or } \\
\text { treatments for fear of being repressed or } \\
\text { prejudiced by health professionals; } \\
\text { Moreover, when they go to the health } \\
\text { service, they prefer to omit their sexual } \\
\text { orientation and are not evaluated } \\
\text { successfully, given that most professionals } \\
\text { are not prepared to offer assistance to } \\
\text { their real demands. }\end{array}$ \\
\hline $\begin{array}{l}\text { The no-go zone: a qualitative study } \\
\text { of access to sexual and } \\
\text { reproductive health services for } \\
\text { sexual and gender minority } \\
\text { adolescents in Southern África. }{ }^{19}\end{array}$ & $\begin{array}{l}\text { ned that health services are } \\
\text { suitable for LGBT adolescents. } \\
\text { face difficulties accessing } \\
\text { ces as a family member is } \\
\text { wever, many of these young } \\
\text { lost ties with their parents by } \\
\text { eeir gender identity and/or } \\
\text { tation. }\end{array}$ \\
\hline $\begin{array}{l}\text { rambling for access: availability, } \\
\text { cessibility, acceptability and } \\
\text { Iality of health care for lesbian, } \\
\text { y, bisexual and transgender } \\
\text { ople in South Africa. }{ }^{20}\end{array}$ & $\begin{array}{l}\text { ing and } \\
\text { srespect } \\
\text { on with } \\
r \text { sexual } \\
\text { ere is a } \\
\text { essionals } \\
\text { e LGBT }\end{array}$ \\
\hline $\begin{array}{l}\text { ing (in)visible in the clinic: a } \\
\text { alitative study of queer, lesbian, } \\
d \text { bisexual women's health care } \\
\text { periences in Eastern Canada. }{ }^{21}\end{array}$ & $\begin{array}{l}\text { ose to leave } \\
\text { ted through } \\
\text { noteworthy } \\
\text { of the fear } \\
\text { ation may }\end{array}$ \\
\hline $\begin{array}{l}\text { Experiences of Transgender-Related } \\
\text { Discrimination and } \\
\text { Implications for Health: Results } \\
\text { From the Virginia Transgender } \\
\text { Health Initiative Study. }{ }^{22}\end{array}$ & $\begin{array}{l}\text { Transgender people are evidently } \\
\text { uncomfortable discussing specific health } \\
\text { care needs with health professionals. It } \\
\text { also describes the delay or even difficulty } \\
\text { in being able to schedule a specific health } \\
\text { service. }\end{array}$ \\
\hline $\begin{array}{l}\text { Ins people's experiences with } \\
\text { isted reproduction services: a } \\
\text { alitative study. }{ }^{23}\end{array}$ & $\begin{array}{l}\text { Some difficulties faced by transsexuals in } \\
\text { contacting assisted reproduction clinics are } \\
\text { reported to be: problems with the } \\
\text { necessary bureaucracy due to } \\
\text { nomenclatures and refusal to care for } \\
\text { these individuals. }\end{array}$ \\
\hline
\end{tabular}

Figure 3. Summary of articles included with their titles and results. Recife (PE), Brazil, 2019.

The results of the primary studies presented in figure 1 were formatted in a textual corpus, analyzing them by the CHD. It is understood that the content of the corpus recognized by IRAMUTEQ 
was composed of texts that contained 3946 meaning indicator words that occurred 18677 times. 513 text segments (TS) were analyzed, corresponding to a total utilization of $89.08 \%$. A good rate of $75 \%$ or more is considered. ${ }^{16-7}$

Through the processing of data, six classes were subdivided and grouped according to the correlation between them that related to aspects of the difficulties faced by LGBT people in health services, namely: invisibility of health specificities; specific public policies; professional misinformation and unpreparedness; vulnerability in the adolescent phase; difficulties in diagnosing sexually transmitted infections and negative experiences (Figure 3). 
J Nurs UFPE on line. 2020;14:e243211

TEXTUAL CORPUS - HEALTH ACCESS DIFFICULTIES BY LESBIANS, GAYS, BISEXUALS, TRANSGENDER PEOPLE

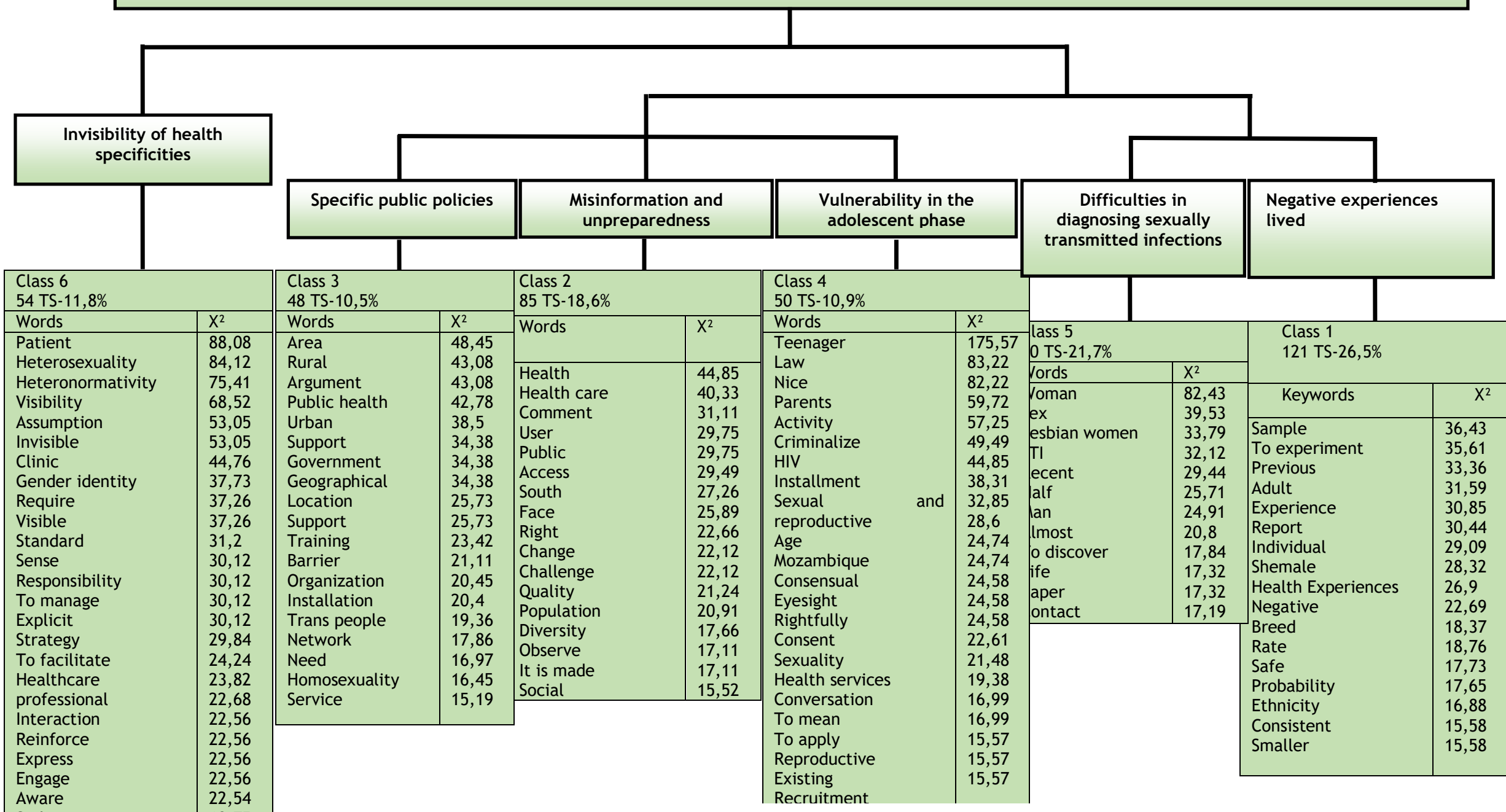

Style

Spread

Figure 4. Thematic structure of the difficulties of access to health by lesbians, gays, bisexuals and transgender people according to the Descending Hierarchical Classification. Recife (PE), Brazil, 2019. 


\section{DISCUSSION}

Sexual orientation is the inclination of the person to be physically and/or emotionally attracted to same-sex (homosexual), opposite-sex (heterosexual) or more than one sex (bisexual). ${ }^{24}$ It is explained that gender identity ${ }^{24}$ It is the selfperception of the individual in relation to their gender, as it is considered as a social construct and may or may not correspond to the sex assigned at birth, and it is in this context that LGBT people suffer from the difficulties of access to health services due to to the tension of heterocisnormativity present in society.

Historically, LGBT people experience social exclusion, prejudice and denial of social rights, being potentiated by contexts of vulnerability. ${ }^{25}$ In this respect, vulnerability is understood as a condition or situation that is associated with various structural relations of domination or injurious forms of identity formation. ${ }^{25}$

It is noted that the invisibility of LGBT health specificities is related to the political and social context, as well as the available structure of access to information, financing and services accessible to the group. ${ }^{25}$ Thus, the dimensions of vulnerability are valid to explain the characteristics and factors that interfere in the health and disease issues of the LGBT population, as well as demonstrate the exclusionary process that they experience and enable the recognition of effective public policies directed to their specifics. $^{2}$

Currently, there are public policies that aim to minimize the existing inequalities in the national LGBT population. Aspects relating to the needs of the LGBT population in Brazil began in 2004 from a resolution in the Human Rights Council entitled "Human Rights, Sexual Orientation and Gender Identity". ${ }^{2}$ It is noted that this was the first resolution to defend the rights of LGBT people, approved by the United Nations (UN), whose purpose was to ensure and legitimize the rights guaranteed to the LGBT population. ${ }^{2}$

In the same year, in Brazil, the "Brazil without Homophobia - Program to Combat Violence, Discrimination against LGBT and the Promotion of Homosexual Citizenship" was established and, in the following years, the Technical Committee on Population Health was established. LGBT and the I National Conference legitimized to LGBT Policy. In 2011, the National LGBT Comprehensive Health Policy was instituted. ${ }^{2}$

It is understood that the National Comprehensive Health Policy for LGBT people was formulated and implemented to combat prejudice in health services and to respect the individualities of each individual in the social and hospital environment. ${ }^{2}$ It is understood that this policy aims to expand access to health services, ensure these individuals respect and the right to use the social name, the provision of quality services and the resolution of their demands, as well as qualify the network of UHS services for the care and integral health care of the LGBT population, quantification and evaluation of health indicators and services for the LGBT population, in addition to ensuring access to the transgender process in the UHS network nationwide. $^{2}$

It is experienced that the implementation of this policy in the daily lives of LGBT people aims to reduce the stigmatizing look, legitimize the use of the social name and promote respect from the awareness of health professionals. ${ }^{2}$ It is argued that the articulation of these actions favors the adherence of LGBT people to health services. ${ }^{26}$

It is understood that these policies are measures that integrate into the recognition of vulnerability, discrimination and exclusion in the health-disease process of the LGBT population. Therefore, it is argued that, in LGBT policy, in addition to promoting the reduction and elimination of discrimination and institutional prejudice, there is the effort to reduce inequalities and consolidate UHS as a universal, integral and equitable system. ${ }^{2}$

The lack of specific LGBT policies favors fear, prejudice and repression from society and health professionals. $^{7,25}$ It is explained that there is a relationship between LGBT individuals and the barriers they suffer from exposing their sexual orientation and/or gender identity in health institutions, thus favoring the non-monitoring and bonding, impacting the situations of vulnerabilities that this group experiences. ${ }^{6,21,25}$

It is evident that LGBT individuals choose not to expose their sexual orientation to health professionals due to fear of discrimination. ${ }^{1,6-7,21}$ In one study, it is argued that most participants agreed with the idea of not disclosing their LGBT identity to health professionals for fear of inappropriate reaction and lack of trust in the health system. ${ }^{27}$

It is noted that specific health care for lesbian women, for example, has been neglected for many years because sexual practice does not involve penile penetration. ${ }^{28}$ It is noted, however, that research on lesbian women and on risky sexual practices gained greater visibility from the 1980s onwards, as there is a possibility of STI infection other than penis/vagina penetration. ${ }^{28}$

It is understood that lesbian women face difficulties that culminate in the lack of access to necessary tests or treatments due to the fear of being repressed. ${ }^{7,21}$ However, it is argued that in order to reduce the prejudice and stigma surrounding the LGBT population, the need for 
continued training of health professionals and the expansion of information to society about gender and public health issues becomes evident in the LGBT public. ${ }^{29-30}$

In this way, ${ }^{29,31}$ continuing education as a way to combat stigma and, therefore, it is necessary that in the training of health professionals, LGBT health issues that address, at a crosscutting manner, risky sexual practices, the numerous types of violence, are discussed, the involvement of infectious diseases, the non-monitoring of chronic diseases and the mental health of that population.

It is shown, in studies, ${ }^{18-9}$ the unpreparedness of health professionals with the health-disease process issues of LGBT people. It is noticed that most professionals are not prepared to meet these individuals fully, do not recognize and delegitimate the various sexual orientations and gender identity, and ignore the existing specificities of the LGBT population, situations that must be addressed in all social and cultural levels. ${ }^{27}$ It is also explained that if, on the one hand, the LGBT population experiences vulnerable situations, on the other, when it comes to LGBT adolescents, these experiences enhance the experiences in health services. ${ }^{19}$

LGBT adolescents, who expose their sexual orientation and or gender identity, are reported to be more susceptible to prejudice and discrimination. $^{32}$ It was evidenced that LGBT adolescents, when seeking access to health services, face more difficulties because the services require the presence of a family member in the consultation. ${ }^{19}$ It is understood that most young people lose ties with their families due to non-acceptance of the heterocisnormative model, which favors contexts of loneliness, sexual work, physical, verbal, psychological, sexual and even death. ${ }^{32}$

It is noteworthy that LGBT adolescents, for the most part, do not receive the necessary information about prevention and health promotion practices, ${ }^{32}$ which favors the search for unreliable means of information, which culminate in the increase of hospitalizations, unprotected sexual practices and, consequently, higher rates of STIs and the human immunodeficiency virus/Acquired Immunodeficiency Syndrome (HIV/AIDS). ${ }^{33}$

It is understood that the involvement of STIs by LGBT individuals may occur due to non-use of condoms, injecting drug use and, above all, lack of knowledge of their serology, factors related to non-access to health services and contribute to the non-treatment, adherence and follow-up of these individuals. ${ }^{27,34}$

It is noted that the LGBT population, for a long time, was the group that was predominantly associated with the involvement and spread of HIV/AIDS. ${ }^{35}$ It is understood that this association, in the early 80 's, was mainly linked to homosexual individuals and transvestites, expanding the stigma, prejudice and homotransphobia contexts already existing in society. ${ }^{34}$

It is evident that, in current studies, the profile of individuals infected with HIV/AIDS has increased significantly in straight and cisgender individuals. ${ }^{36}$ Between 2010 and 2016, 125,806 new cases were reported in cisgender men and 62,920 new cases in cisgender women. Among men, over $75 \%$ were found to be heterosexual; among women, it was noted that this figure reached more than $85 \%,{ }^{36}$ characterizing that the profile of people affected by HIV/AIDS has changed remarkably, although there is still an association of this disease with the LGBT population.

However, even with specific public policies to combat the HIV/AIDS epidemic and health for LGBT people, the stereotype, stigma and perspective that this population suffers, especially transgender, homosexual people, is discussed. and men who have sex with men (MSM). ${ }^{35}$

It is furthermore identified that transgender people face the most difficulties in seeking care in health services and it is understood that they happen not only when they claim specialized services but also in the search for routine health services, like performing blood tests and quick tests. $^{38}$

Note the importance of public policies for the insertion of the LGBT population in health services as necessary and indispensable. It is argued that this is a strategy that ensures the expansion of health services to this public and seeks not only to decrease, but also to increase the supply of information regarding infections by STIs, the monitoring of chronic diseases and treatment directed to their specificities, like hormone use and psychological counseling. ${ }^{2}$

\section{CONCLUSION}

It is evident that access to health services by the LGBT population is permeated by constraints and prejudices. Exclusion, helplessness, omission and indifference to access are understood as characteristics and feelings evidenced by this public, even in the face of specific public policies aimed at eliminating the prejudice and stigma that this population suffers. Professional unpreparedness in meeting the specificities of the LGBT population is also mentioned, as well as their fear of verbalizing their sexual orientation and or gender identity due to the prejudice they may suffer.

It is also explained that studies are incipient about access to health services for LGBT people, especially in Brazil. Thus, further studies are 
recommended that address the issue in a full perspective and consider the specific factors of each country. Finally, it is noted that this study is necessary evidence, as it demonstrates results from worldwide recognized studies and, thus, aims to broaden access to information, especially with regard to the perception of the population and organs of the health system.

\section{REFERENCES}

1. Supremo Tribunal Federal (BR). Constituição da República Federativa do Brasil [Internet]. Brasília: Supremo Tribunal Federal; 1988 [cited 2019 July 12]. Available from: http://www.stf.jus.br/arquivo/cms/legislacaoCon stituicao/anexo/CF.pdf

2. Ministério da Saúde (BR), Secretaria de Gestão Estratégica e Participativa, Departamento de Apoio à Gestão Participativa. Política Nacional de Saúde Integral de Lésbicas, Gays, Bissexuais, Travestis e Transexuais [Internet]. Brasília: Ministério da Saúde; 2011 [cited 2019 July 12]. Available from: http://bvsms.saude.gov.br/bvs/publicacoes/politi ca_nacional_saude_lesbicas_gays.pdf

3. Catão MÓ, Farias CLD, Lima DMC, Góes LCM. Social exclusion of the rights of citizenship: patterns andpopulation lgbt mishaps of Campina Grande - PB [Internet]. 2015 Jan/Apr [cited 2019 Mar 6];1(7):05-30.

DOI:

10.20887/rdtv.ccj.2015.v7i1p5-30

4. Dahlhamer JM, Galinsky AM, Joestl SS, Ward BW. Barriers to health care among adults identifying as sexual minorities: a US National Study. AJPH. 2016 June;6(106):1116-22. DOI: 10.2105/AJPH.2016.303049

5. Macapagal K, Bhatia R, Greene GJ. Differences in healthcare access, use, and experiences within a community sample of racially diverse lesbian, gay, bisexual, transgender, and questioning emerging adults. LGBT Health. 2016;6(3):434-42. DOI: $10.1089 /$ lgbt.2015.0124

6. Oliveira GS, Nogueira JA, Costa GPO, Silva FV, Almeida SA. Access by lesbians, gays, bisexuals and transvestites/transsexuals to the basic family health units. Rev RENE. 2018 June;3295(19): 1-7. DOI: $10.15253 / 2175-6783.2018193295$

7. Seibel BL, Falceto OG, Hollist CS, Springer P, Fernandes CLC, Koller SH. Social support and family functioning: longitudinal study of vulnerable families. Pensando fam [Internet]. 2017 July [cited 2019 June 28];21(1):129-36. Available from:

http://pepsic.bvsalud.org/pdf/penf/v21n1/v21n1 a10.pdf

8. Silberman P, Buedo PE, Burgos LM. Barriers to sexual health care in Argentina: perception of women who have sex with women. Rev salud pública. $2016 \quad$ Feb;1(18):1-12. DOI: 10.15446/rsap.v18n1.48047

9. Ercole F, Melo LS, Laís S, Alcorofado CLGC. Integrative review versus systematic review. REME Rev Min Enferm. 2014 Jan/Mar;18(1):1-260. DOI: 10.5935/1415-2762.20140001

10. Soares CB, Hoga LAK, Peduzzi M, Sangaleti C, Yonekura T, Silva DRAD. Integrative review: concepts and methods used in nursing. Rev esc enferm USP. 2014 Apr;48(2):335-45. DOI: 10.1590/S0080-6234201400002000020

11. Apóstolo JLA. Síntese da evidência no contexto da translação da ciência [Internet]. Coimbra: Escola Superior de Enfermagem de Coimbra; 2017 [cited 2019 Sept 15]. Available from:

https: / /www.esenfc.pt/pt/download/3868/dXeLM hjdjCvHFwDpAvDd

12. Magno L, Silva LAV, Veras MA, Santos MP, Dourado I. Stigma and discrimination related to gender identity and vulnerability to HIV/AIDS among transgender women: a systematic review. Cad Saúde Pública. 2019 Apr;35(4):1-21. DOI: 10.1590/0102-311X00112718

13. Stetler CB, Morsi D, Ruck S, Broughton S, Corrigan B, Fitzgerald J, et al. Utilization focused integrative reviews in a nursing service. Appl Nurse Res. 1998 Nov;(4):195-206. DOI: 10.1016/s0897-1897(98)80329-7

14. Milton K. Primary care trust: critical appraisal kills programme: making sense of evidence. London: Oxford; 2002

15. Galvão TF, Pansani TSA, Harrad D. Principais itens para relatar Revisões sistemáticas e Metaanálises: A recomendação PRISMA. Epidemiol Serv Saúde. 2015 Apr/June;24(2):335-42. DOI: 10.5123/S1679-49742015000200017

16. Ursi ES, Galvão CM. Perioperative prevention of skin injury: an integrative literature review. Rev Latino-Am Enfermagem [Internet]. 2016 Jan/Feb;14(1):124-31. DOI: 10.1590/S010411692006000100017

17. Camargo BV, Justo AM. IRAMUTEQ: a free software for analysis of textual data. Temas psicol. 2013 Dec;21(2):513-18. DOI: 10.9788/TP2013.2-16

18. Hirsch 0 , Löltgen $K$, Becker A. Lesbian womens' access to healthcare, experiences with and expectations towards GPs in German primary care. BMC Family Practice. 2016 Nov;17(1):162. DOI: https://10.1186/s12875-016-0562-4

19. Müller A, Spencer S, Meer T, Daskilewicz K. The no-go zone: a qualitative study of access to sexual and reproductive health services for sexual and gender minority adolescents in Southern Africa. BMC Reprod Health. 2018 Feb;15(12):0115. DOI: $10.1186 / \mathrm{s} 12978-018-0462-2$ 
20. Müller A. Scrambling for access: availability, accessibility, acceptability and quality of healthcare for lesbian, gay, bisexual and transgender people in South Africa. BMC Int Health Hum Rights. 2017 May;17(1):16. DOI: 10.1186/s12914-017-0124-4

21. Fredericksa A, Harbinb A, Bakerc K. Being (in)visible in the clinic: a qualitative study of queer, lesbian, and bisexual women's health care experiences in Eastern Canada. Health Care Women Int. 2017 Apr;38(4):394-408. DOI: 10.1080/07399332.2016.1213264

22. Bradford J, Reisner SL, Honnold JA, Xavier J. Experiences of transgender-related discrimination and implications for health: results from the Virginia Transgender Health Initiative Study. Am J Public Health. 2016 Oct;103(10):1820-9. DOI: 10.2105/AJPH.2012.300796

23. Abra SJ, Tarasoff LA, Green D, Epstein R, Anderson S, Marvel S, et al. Transpeople's experiences with assisted reproduction services: aqualitative study. Human Reprod. 2015 June; 6(30):1365-74. DOI: 10.1093/humrep/dev087

24. Albuquerque GA, Garcia CL, Alves MJH, Queiroz CMHT, Adami F. Homosexuality and the right to health: a challenge for health policies in Brazil. Saúde Debate. 2015 July/Sept;37(98):51624. DOI: $10.1590 /$ S0103-11042013000300015

25. Ayres JRCM, França Júnior I, Calazans GJ, Saletti Filho HC. The vulnerability concept and the practices of health: new perspectives and challenges. In: Czeresnia D, Freitas CM. Promoção da saúde: conceitos, reflexões, tendências. Rio de Janeiro: FIOCRUZ, 2003.

26. Querino MS, Almeida SS, Oliveira SCS, MoraesFilho IM. Nursing team's actions for implementing the politic for lesbians, gays, bisexuals, travesties and transsexualsliterature review. Rev Cient Sena Aires [Internet]. 2017 Jan/June [cited 2019 Jul 1];6(1):46-58. Available from: http://revistafacesa.senaaires.com.br/index.php/ revisa/article/view/277

27. Crenitte MRF, Miguel DF, Jacob Filho W. An approach to the peculiarities of lesbian, gay, bisexual, and transgender aging. Geriatr Gerontol Aging. 2019 Mar;13(1):50-6. DOI: 10.5327/Z2447211520191800057

28. Cabral KTF, Pereira IL, Almeida LR, Nogueira WBAG, Silva FV, Costa LFP, et al. Nursing care for lesbian and bisexual women. J Nurs UFPE on line [Internet]. 2019 Jan [cited 2019 July 23];13(1):7985. Available from: https://periodicos.ufpe.br/revistas/revistaenferm agem/article/view/237896/31188

29. Campos KFC, Sena RR, Silva KL. Permanent professional education in healthcare services. EsC Anna Nery Rev Enfer. 2017 July;21(4):1-10. DOI: 10.1590/2177-9465-EAN-2016-0317
30. Gomes SM, Sousa LMP, Vasconcelos TM, Nagashima AMS. SUS out of the closet: conceptions of municipal health managers on the LGBT population. Saúde Soc. 2018 Oct/Dec;4(27):112033. DOI: $10.1590 /$ S0104-12902018180393

31. Negreiros FRN, Ferreira BO, Freitas DN, Pedrosa JIS, Nascimento EF. Health of lesbians, gays, bisexuals, transvestites and transsexuals: from medical training to professional activities. Rev Bras Educ Med. 2019 Jan/Mar;43(1):23-31. DOI: 10.1590/1981-52712015v43n1RB20180075

32. Fundo das Nações Unidas para a Infância. 0 direito de ser adolescente: oportunidade para reduzir vulnerabilidades a superar desigualdades [Internet]. Brasília: UNICEF; 2011 [cited 2019 July 02]. Available from: https://www.tjdft.jus.br/informacoes/infancia-ejuventude/publicacoes-textos-e-

artigos/publicacoes/publicacoes-1/situacao-daadolescencia-brasileira-2011

33. DiClemente RJ, Ponton LE, Hansen WB. New Directions for Adolescent Risk Prevention and Health Promotion Research and Interventions. In: DiClemente RJ, Hansen WB, Ponton LE, editors. Handbook of Adolescent Health Risk Behavior. Issues in Clinical Child Psychology. Boston: Springer; 1996.

34. Mora C, Brigeiro M, Monteiro S. HIV Testing Among "MSM": Prevention Technologies, Sexual Moralities and Serologic Self-surveillance. Physis. 2018 Aug;28(2):e280204. DOI: 10.1590/S010373312018280204

35. Greco DB. Thirty years of confronting the Aids epidemic in Brazil, 1985-2015. Ciênc aúde Colet. 2016 May;21(5):1553-64. DOI: 10.1590/141381232015215.04402016

36. Feitosa PWG, Oliveira IGP, Maia MAG, Martins MVF, Rodrigues EHC, Felix EBG, et al. From "gay plague" to AIDS supremacy among heterosexuals in Brazil. Id on Line Rev Mult Psic [Internet]. 2018 [cited 2019 July 23];12(42):651-61. Available from:

https://idonline.emnuvens.com.br/id/article/vie $\mathrm{w} / 1479$

37. Oliveira Júnior JM, Moreira NR. Políticas Públicas de controle das DST's entre a população LGBT de Itabuna (BA). In: IV Seminário Enlaçando Sexualidades. Anais do IV Seminário Enlaçando Sexualidades. 2015. [Internet]. Salvador: UNEB; 2015 [cited 2019 Aug 25]. Available from: https: / / docplayer.com.br/15790280-Politicaspublicas-de-controle-das-dst-s-entre-a-populacaolgbt-de-itabuna-ba-palavras-chave-saudeconscientizacao-direitos-humanos.html

38. Rocon PC, Rodrigues A, Zamboni J, Pedrini $M D$. Difficulties experienced by trans people in accessing the Unified Health System. Ciênc Saúde Coleti 2016 Aug;21(8):2517-25. DOI: 10.1590/1413$\underline{81232015218.14362015}$ 
Corresponding author

Alef Diogo da Silva Santana

Email: allef.diogo@gmail.com

Submission: 2019/11/08

Accepted: 2019/12/27

Copyright $\odot 2019$ Journal of Nursing UFPE on line/JNUOL.

(oc) EY This is an Open Access article distributed under the terms of the Creative Commons AttributionShareAlike 4.0 International License. This license lets others distribute, remix, tweak, and build upon your work, even commercially, as long as they credit you for the original creation. Recommended for maximum dissemination and use of licensed materials. 